\title{
Place of non-contrast computed tomography for evaluation of flank pain and suspected urinary stone in emergency service
}

\author{
Acil serviste yan ă̆rısı ve şüpheli üriner taşın değerlendirilmesi için non- \\ kontrast bilgisayarlt tomografinin yeri
}

\section{İsmail Şalk*, Ali Çetin, İlhan Korkmaz, Ferhat Sezer, Mehmet Haydar Atalar}

Departments of Radiology (Assist. Prof. İ. Şalk, MD, F. Sezer, MD, Assoc. Prof. M. H. Atalar), Department of Obstetrics and Gynecology (Prof. A. Çetin, MD), Department of Emergency Medicine (Assist. Prof. İ. Korkmaz, MD), Cumhuriyet University School of Medicine, TR-58140 Sivas

\begin{abstract}
Aim. With an intent to present our experience with the non-contrast computed tomography (CT) during the work-up of patients admitted with acute urinary complaints in the emergency service, we reviewed our clinical and non-contrast CT imaging data of patients presented with flank pain and suspected urinary stone. Methods. Clinical and non-contrast CT with ultrasound examinations performed at our Emergency and Radiology Departments in 2011 were reviewed retrospectively in 102 adult urinary stone patients in acute conditions. Results. In 102 patients with suspected urinary stones, 95 had urinary stones detected with non-contrast CT. Ultrasonography provided helpful findings for the evaluation of calyceal dilatation and hydronephrosis. There was no specific side and level preference of urinary stones in the urinary tract. There was no hydronephrosis in for the percent of urinary stone patients. The BUN and creatinine levels in the patients with multiple urinary stones were higher than those in the patients with single urinary stones $(\mathrm{p}<0.05)$. Although single urinary stone was more common, overall there was no specific propensity of single and multiple urinary stones to kidney, ureter, and bladder. Conclusions. In this study, we attempted to reveal the efficacy of non-contrast CT during the diagnosis of urinary stones in patients presenting to the Emergency Department in acute conditions. According to our findings, non-contrast CT with ultrasound is diagnostic modality for patients with urinary stones in the Emergency Department. Further studies are needed to shed light on the long-term effects of the choice of this pathway on the clinicoradiologic diagnosis of urinary stone patients. According to our findings, non-contrast CT with ultrasound is diagnostic modality for patients with urinary stones in the Emergency Department. Further studies are needed to shed light on the long-term effects of the choice of this pathway on the outcome of urinary stone patients.
\end{abstract}

Keywords: Urinary stone, emergency department, non-contrast computed tomography, ultrasonography

\section{Özet}

Amaç. Acil servise akut üriner şikayetlerle başvuran hastaların incelenmesi sırasında kontrastsız bilgisayarlı tomografi (BT) ile ilgili tecrübelerimizi sunmak amacı ile yan ağrısı ile gelen ve şüpheli üriner taşı olan hastaların klinik ve kontrastsız (BT) verilerini değerlendirdik. Yöntem. Klinik, kontrastsız BT ve ultrasonografi (US) incelemeleri 2011 yılında acil ve radyoloji departmanlarında yapılan 102 adet erişkin akut üriner taş hastasında retrospektif olarak değerlendirildi. Bulgular. Değerlendirilen 102 olgunun 95 tanesinde kontrastsız BT'de taş1 mevcuttu. Ultrasonografi kaliks dilatasyonu ve hidronefrozun değerlendirilmesinde yardımcı bulgular sağladı. Üriner sistemde üriner taşların spesifik bölgesi ve seviye tercihi bulunmamaktaydı. Multipl üriner taşı olan hastalarda BUN ve kreatinin seviyeleri tek üriner taşı olan hastalardan daha yüksekti $(\mathrm{p}<0,05)$. Tek üriner taş sayısı daha sık olduğu halde tek ve multipl taşların böbrek, üreter ve mesanede bulunma oranı özellik göstermiyordu. Sonuçlar. Bu çalışmada akut durumlarda Acil servise başvuran hastalarda üriner taşların tanısı sırasında kontrastsız BT'nin etkinliğini göstermeyi amaçladık. Bizim bulgularımıza göre US ile birlikte kontrastsız BT Acil serviste üriner taşlı hastalar için tanısal modalitedir. Üriner taşlı olguların klinikoradyolojik tanıları üzerinde önerdiğimiz yolun tercih edilmesinin etkilerini aydınlatmak için daha fazla çalışmalara ihtiyaç vardır.

Anahtar sözcükler: Üriner taş, acil servis, non-kontrast bilgisayarlı tomografi, ultrasonografi 
Geliş tarihi/Received: February 17, 2014; Kabul tarihi/Accepted: March 12, 2014

\section{*Corresponding author:}

Dr. İsmail Şalk, Radyoloji Anabilim Dalı, Cumhuriyet Üniversitesi Tıp Fakültesi, TR-58140 Sivas. E-mail: ismailsalk@gmail.com

\section{Introduction}

Non-contrast computed tomography (CT) gained important role with high sensitivity (98\%) and specificity (96\%-98\%) for detection of urinary stones [1]. There are many advantages of non-contrast $\mathrm{CT}$ such as short examination time, ability to detect almost all types of urinary stones and extra-urinary causes of flank pain, and no risk of contrast media injection [2, 3]. Appendicitis, diverticulitis, and gynecological or vascular disorders need to be considered during differential diagnosis of urinary stones.

Nowadays, in the era of advanced techniques like CT and ultrasonography (US), the value of abdominal x-ray (AXR) is decreased considerably. Especially, in cases with negative results, there is a need for additional imaging work-up. AXR should be ordered for specific conditions such as urolithiasis patients with a history of radiopaque stone formation in order to reduce its unnecessary requests [4]. AXR has limited diagnostic benefits because of several factors such as bowel gas, extra renal calcifications, and obesity. These factors reduce the sensitivity of AXR for the diagnosis of urinary stones. Intravenous urography (IVU) detects urinary stones in 31\%-48\% of cases and has the risk of anaphylaxis related to the injection of contrast media [5].

In clinical practice, US gained important place for scanning of urinary system abnormalities. US has a diagnostic value in some of the patients in the assessment of urolithiasis, especially its dependence to the operator and its pitfalls during evaluation of distal ureteral calculi [6]. Although experience is considerably important for detection of urinary stones, there are studies attempting to increase its sensitivity. CT, US, and colorDoppler US with can be useful as complementary techniques for detecting urinary stones $[7,8]$.

Since 1990s, non-contrast CT has become the method of choice for the evaluation of urolithiasis in the emergency department and replaced AXR and IVU [9, 10]. Noncontrast CT performed to investigate whether there is urolithiasis accounts for nearly $22 \%$ of all CT examinations of the evaluation of acute abdominal pain $[11,12]$.

In patients admitted to the emergency service, urinary stones are a relatively common problem and a frequent emergency service diagnosis in patients who present with acute flank and lower abdominal pain. Disorders related to urinary stones are associated with significant and increasing costs to the medical system [13]. While there is a decreased popularity of other imaging modalities such as intravenous pyelography, renal US, and AXR for the assessment of kidneys, ureters, and bladder, nowadays, non-contrast CT is becoming method of choice in the evaluation of patients with suspected urinary stone owing to its high sensitivity and specificity for all types of urolithiasis. During assessment of patients admitted to the emergency service, we prefer non-contrast CT with urinary US in cases with a complaint of pain possibly related to the urinary stone in current practice. With intent to contribute to the knowledge related to non-contrast CT during the work-up of patients admitted with acute urinary complaints in the emergency service, we reviewed our clinical and non-contrast CT imaging data of patients admitted for the evaluation of flank pain and suspected urinary stone.

\section{Materials and methods}

After the approval of Human Ethics Committee of Cumhuriyet University, this study retrospectively reviewed electronically available notes for patients who met inclusion 
criteria. Inclusion criteria were being seen in the Emergency Department (ED) in 2011, ED diagnosis of urinary stone; complaints of flank/lower abdominal pain with or without urinary symptoms; imaging with non-contrast CT with ultrasonography; and adult patient. Patients were excluded if they had a previous diagnosis of urinary stone and a history of trauma.

After ultrasonographic examination of urinary system from kidney to bladder, CT scanning was performed. Ultrasonographic evaluation was performed with Acuson Antares Ultrasonography System (Siemens Medical Solutions USA, Inc., Mountain View, CA, USA). The CT scanner used in this study was a 128-detector-row CT scanner (Aquilion, Toshiba Medical Systems, Tokyo, Japan) and with $250 \mathrm{mAs}, 120 \mathrm{kVp} 3 \mathrm{~mm}$ collimation and scanned from the dome of the diaphragm to the symphisis pubis. The acquisition time ranged from 13 to 15 seconds. About 250 images were generated per patient. No contrast medium was administered. This is the standard protocol utilized at our university hospital. The images analyzed at a workstation that was capable of reconstruction processing. Two radiologists evaluated all images. Interobserver and intraobserver reliability was determined as Kappa coefficient ranged from 0.74-0.84 and $0.76-0.82$, respectively.

Age, gender, BMI, presence of blood (microscopic hematuria) and calcium oxalate in urine, and blood urea nitrogen and serum creatinine levels were determined. Stone dimensions were recorded in all cases. Stone locations were categorized as kidney, proximal, middle, and distal ureter as well as the stone number as single or multiple. Location of calyceal dilatation, side of ureteral dilatation, and ratio of hydronephrosis were recorded according to the findings of US evaluation.

Data were presented as mean $\pm \mathrm{SD}$ or percentage, or number. Chi-square and test were used for analyses of clinical data. A p value of less than 0.05 was accepted as significant.

\section{Results}

Age, gender, BMI, microhematuria, calcium oxalaturia, and ureteral dilation were shown in Table 1. Of 102 patients, 95 had urinary stones as single or multiple in kidney or ureter. There was no patient with urinary stone in bladder. We found that the presence of microhematuria and absence of calcium oxalate in urine samples were prominent. The ratios of ureteral dilation sites were comparable as none, right, or left.

Table 1. Selected clinical and urinary data of study population.

\begin{tabular}{ll}
\hline Characteristics & Patients $(\mathbf{n = 1 0 2})$ \\
\hline Age $($ mean $\pm \mathrm{SD})$ & $41.5 \pm 17.1$ \\
Gender $(\mathrm{F} / \mathrm{M})$ & $40 / 62$ \\
BMI & $24.44 \pm 4.28$ \\
\hline Microhematuria & \\
Present & $86(84.3 \%)$ \\
Absent & $16(15.7 \%)$ \\
\hline Urine Ca oxalate & \\
Present & $11(10.8 \%)$ \\
Absent & $91(89.2 \%)$ \\
\hline Ureteral dilatation & \\
None & $37(36.3 \%)$ \\
Right & $33(32.4 \%)$ \\
Left & $32(31.4 \%)$ \\
\hline
\end{tabular}

Figure 1 presents the ratios of presence and location of calyceal dilatation of patients with urinary stones $(n=95)$ with ultrasonographic and non-contrast $\mathrm{CT}$ examinations. The ratio of patients with none or all calyces dilated was higher than compared to the other types of calyceal dilatation. 


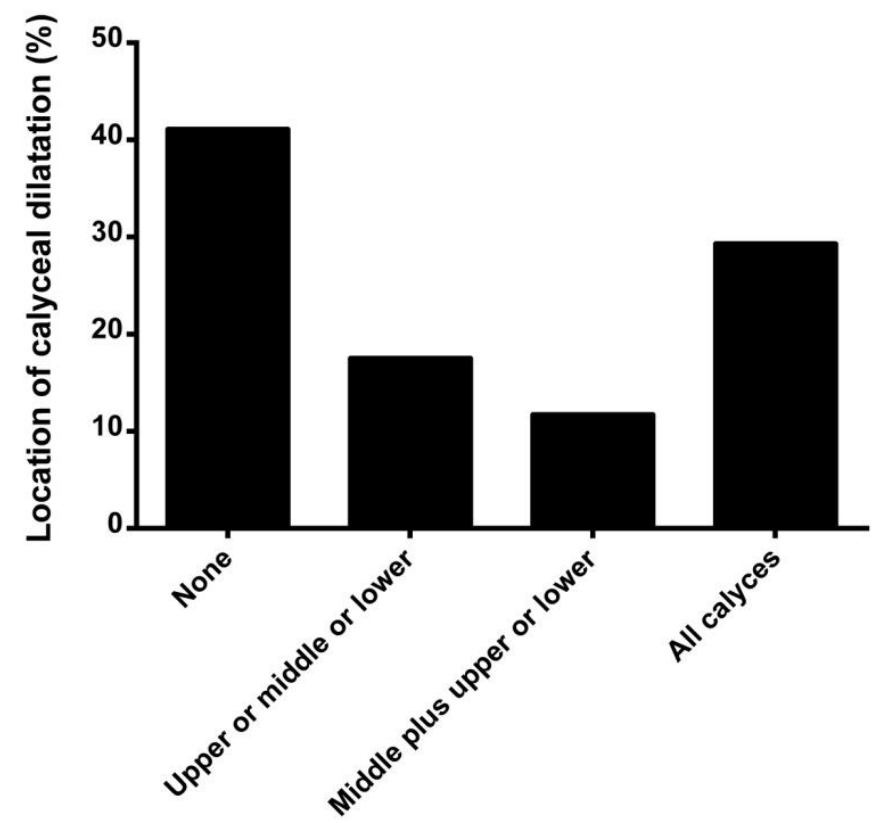

Figure 1. Location of calyceal dilatation of the patients with urinary stones $(n=95)$.

Figure 2 shows the BUN and creatinine levels of the patients grouped according to presence of single or multiple urinary stones. The BUN and creatinine levels in the patients with multiple urinary stones were higher than those in the patients with single urinary stones $(\mathrm{p}<0.05)$.

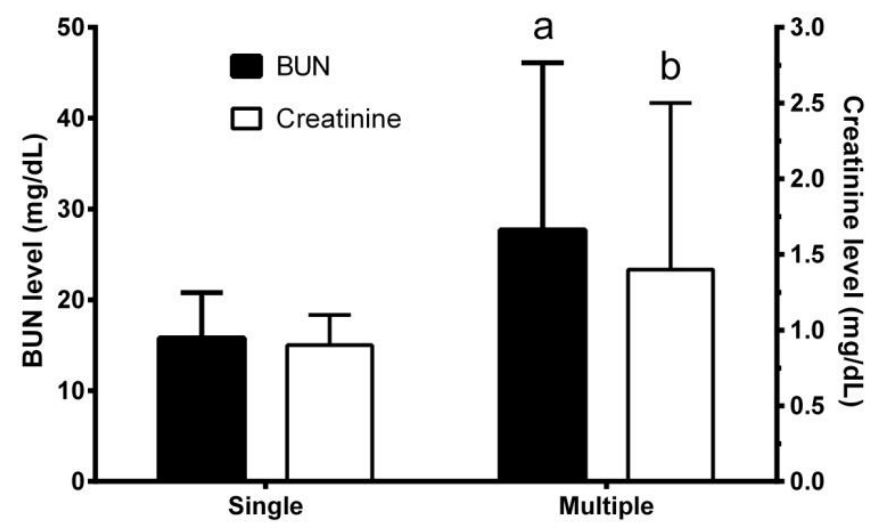

Figure 2. BUN and creatinine levels of based on number of calculi (single or multiple).

${ }^{a, b} \mathbf{P}<0.05$ vs. single group.

Figure 3 displays impact of location of ureter stones on hydronephrosis. There was no significant difference in the ratio of hydronephrosis related to location of ureter stone $(\mathrm{p}>0.05)$. 


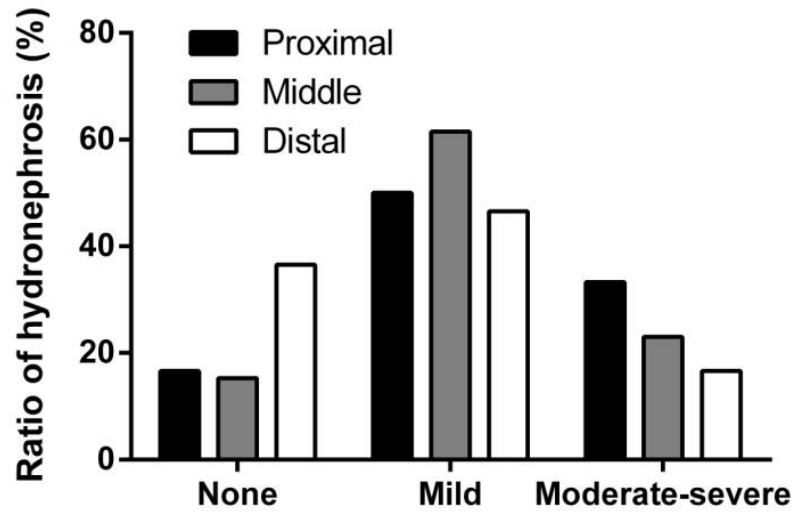

Figure 3. Impact of location of ureter stones on hydronephrosis. Ureter was divided into three parts; proximal, middle, and distal.

Figure 4 presents the calculus diameter of patients according to presence of ureteral dilatation. In patients with ureteral dilatation, calculus diameter was significantly higher compared to that of patients without ureteral dilatation $(4.2 \pm 2.8$ vs. $2.3 \pm 1.3 ; \mathrm{p}<0.05)$.

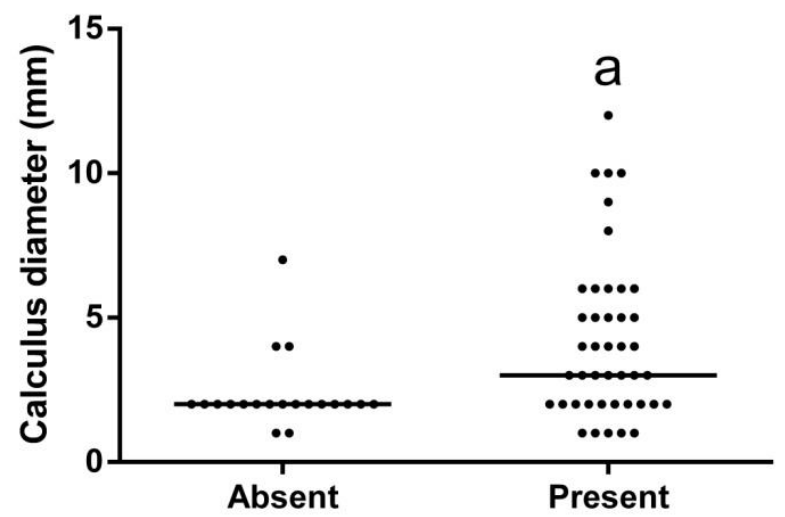

Figure 4. Presence of ureteral dilatation according to diameter of ureteral calculi measured with non-contrast CT.

${ }^{\text {a }} \mathbf{P}<0.05$ vs. absent of ureteral dilatation group.

Figure 5 displays stone locations and whether the stone found as single or multiple in the study population. The number of patients with single stones on left side is more than that on the right side in the ureter contrary to the kidney. According to the number of patients with multiple stones, overall, there was no site preference of multiple stones as right or left kidney, bilateral kidneys, right and left kidney and ureter, right kidney plus left ureter, and left kidney plus right ureter. 


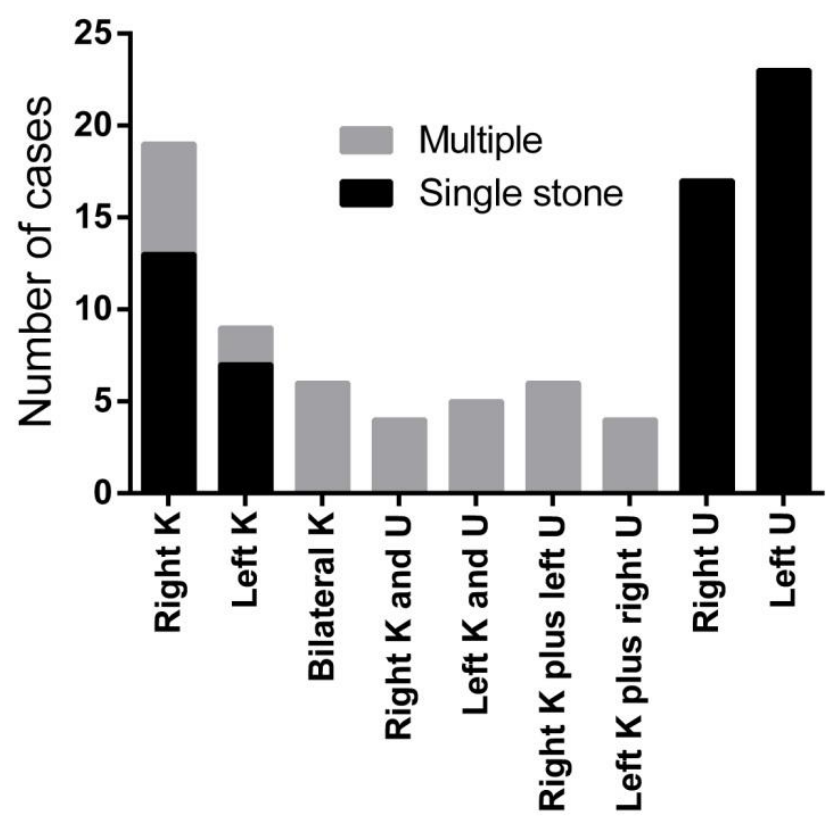

Figure 5. Location and number of urinary stones in the study population $(n=95)$.

The numbers of stones were displayed as single or multiple. K, kidney; U, Ureter.

\section{Discussion}

In 102 patients with suspected urinary stones, 95 had urinary stones detected with noncontrast CT. Ultrasonography was found helpful for the evaluation of calyceal dilatation and hydronephrosis. In our study population, the presence of urinary oxalate was lower than expected. Of patients with calyceal dilatation, we found that the calyceal dilatation of all calyces were prominent. Of patients with urinary stones, the ratio of no calyceal dilatation was more than the ratio of other calyceal dilation types. As maybe expected, the BUN and creatinine levels of patients with multiple urinary stones were meaningfully higher compared to patients with single urinary stones. According to the location of urinary stone in the ureter as proximal, middle, or distal ureter, the ratio of severity of hydronephrosis was found comparable. In patients with ureteral dilatation, calculus diameter was more than that of patients without ureteral dilatation. As single urinary stone, left ureter, right ureter, right kidney, and left kidney in rank was more preferred sites. As multiple urinary stones, the site preference was distributed and there was no specifically selected location.

With non-contrast CT, calcified and non-calcified urinary stones may be identified, along with the location and size of the stone from kidney to bladder. Secondary signs of obstructive uropathy, including hydronephrosis and ureteral ecstasies. On non-contrast $\mathrm{CT}$, calcified urinary stones appear as opaque densities within the urinary tract as seen on AXRs. Interestingly, non-calcified urinary stones those are radiolucent on AXR can also seen as calcified urinary stones on non-contrast CT. To differentiate calcified and noncalcified urinary stones according to their appearance is not possible. Degree of accuracy in interpreting a non-contrast CT in a case with urinary stone increases in accordance with the severity of urinary obstruction [14-16].

Previous studies demonstrated that CT allowed diagnosis and determining the size, composition, and location of stones. Tisdale et al. [17] analyzed the correlation between stone dimensions assessed with CT and plain radiography of the kidneys, ureter and bladder. The accurate assessment of stone size were important as it was related to the 
success of treatment with SWL [18, 19]. Liu et al. [20] demonstrated a sensitivity of 97\%, specificity of $96 \%$, and accuracy of $97 \%$ in evaluation of calculi in a study of 60 patients. Identification of the number, size, and location of urinary stones and detection of hydronephrosis are easily made with CT [21, 22]. The ED is a common setting for evaluation of patients with urinary stones based on acute symptoms and a propensity for repeated presentations requiring optimization of clinical approaches to improve the efficacy of acute care for urinary stone patients [23].

In contrast to non-contrast $\mathrm{CT}$, magnetic resonance imaging (MRI) may provide higher sensitivity and specificity for detection and measure of the secondary effects of clinically active urinary stone, including ureteral dilatation and measures of altered renal function [24]. MRI, like ultrasonography is an alternative modality to radiation-based non-contrast CT, of particular importance in children and pregnant patients. Kalb et al. [24] stated that the cost-benefits of MRI in the setting of ED patient for acute care of renal colic remains an area for continued study and that MRI may be helpful in patients with symptomatic urinary stones. According to our experience, during the examination of patients with acute and severe pain, non-contrast CT is completed in short time and found considerably tolerable.

Ripollés et al. [25] and Winkel et al. [7] conducted prospective studies to evaluate the usefulness of the twinkling artefact (TA) seen on color-Doppler ultrasound images during diagnosing urolithiasis. Winkel et al. [7] performed ultrasonography and color-Doppler ultrasonography with CT. They suggested that during color-Doppler ultrasonography, the TA was a useful contribution for detecting urolithiasis $[7,25]$ in patients especially when CT was contraindicated [7].

Rafi et al. [26] noted that patients presenting to the ED with complaints related to urinary stone benefited from early and accurate detection by CT imaging. They stated that early completion of CT examination and assessment of radiologic findings may hasten the management of urinary stone disease. In our study, all non-contrast CT and ultrasound examinations were assessed to determine the presence of acute urinary abnormalities including urinary stones and dilatations as real-time decisions in the radiology department.

Although we mentioned potential benefits of the use of non-contrast CT in the evaluation of acute abdominal pain related to the urinary stone, there are challenges remaining to be addressed. For differential diagnosis of gastrointestinal and gynecologic disorders, there may be need to other imaging modalities such as MRI, US, and AXR. Considering the limitations of US related to urinary stones less than $3 \mathrm{~mm}$ and urinary stones of ureter, non-contrast CT has important advantages related to its ability to detect the size, location and dansity of urinary stones as a method of choice. There is a need to balance the higher per-study cost of imaging modalities with the lower post-study benefits derived from the additional diagnostic information that may lead to less total number of tests and more precisely delivered therapies. Results of this study suggests that non-contrast CT can be preferred as the first modality during the work-up of cases with urinary stone admitted to the ED.

\section{References}

1. Wang JH, Shen SH, Huang SS, Chang CY. Prospective comparison of unenhanced spiral computed tomography and intravenous urography in the evaluation of acute renal colic. J Chin Med Assoc 2008; 71: 30-6.

2. Rodríguez Alonso A, Pérez García D, Ojea Calvo A, Rodríguez Iglesias B, Alonso Rodrigo A, Barros Rodríguez JM, Benavente Delgado J, Nogueira March JL. Value of non-contrast helical computerized tomography in nephrotic colic assessment. Actas Urol Esp 1999; 23: 772-7.

3. Franco A, Tomás M, Alonso-Burgos A. Intravenous urography is died. Long live the computerized tomography! Actas Urol Esp 2010; 34: 764-74. 
4. Gans SL, Stoker J, Boermeester MA. Plain abdominal radiography in acute abdominal pain; past, present, and future. Int J Gen Med 2012; 5: 525-33.

5. Jindal G, Ramchandani P. Acute flank pain secondary to urolithiasis: Radiologic evaluation and alternate diagnoses. Radiol Clin North Am 2007; 45: 395-410.

6. Sandhu C, Anson KM, Patel U. Urinary tract stones--Part I: role of radiological imaging in diagnosis and treatment planning. Clin Radiol 2003; 58: 415-21.

7. Winkel RR, Kalhauge A, Fredfeldt KE. The usefulness of ultrasound colourDoppler twinkling artefact for detecting urolithiasis compared with low dose nonenhanced computerized tomography. Ultrasound Med Biol 2012; 38: 1180-7.

8. Magrill D, Patel U, Anson K. Impact of imaging in urolithiasis treatment planning. Curr Opin Urol 2013; 23: 158-63.

9. Smith RC, Rosenfield AT, Choe KA, Essenmacher KR, Verga M, Glickman MG, Lange RC. Acute flank pain: comparison of non-contrast-enhanced CT and intravenous urography. Radiology 1995; 194: 789-94.

10. Saw KC, McAteer JA, Monga AG, Chua GT, Lingeman JE, Williams JC Jr. Helical CT of urinary calculi: effect of stone composition, stone size, and scan collimation. AJR Am J Roentgenol 2000; 175: 329-32.

11. Rosen MP, Siewert B, Sands DZ, Bromberg R, Edlow J, Raptopoulos V. Value of abdominal CT in the emergency department for patients with abdominal pain. Eur Radiol 2003; 13: 418-24.

12. Kambadakone AR, Eisner BH, Catalano OA, Sahani DV. New and evolving concepts in the imaging and management of urolithiasis: urologists' perspective. Radiographics 2010; 30: 603-23.

13. Eaton SH, Cashy J, Pearl JA, Stein DM, Perry K, Nadler RB. Admission rates and costs associated with emergency presentation of urolithiasis: analysis of the Nationwide Emergency Department Sample 2006-2009. J Endourol 2013; 27: 1535-8.

14. Rao S. Acute Obstructive Uropathy Imaging. Available at: www.medscape.com (Accessed on January 2014).

15. Smith RC, Verga M, Dalrymple N, McCarthy S, Rosenfield AT. Acute ureteral obstruction: value of secondary signs of helical unenhanced CT. AJR Am J Roentgenol 1996; 167: 1109-13.

16. Johnson EK, Faerber GJ, Roberts WW, Wolf JS Jr, Park JM, Bloom DA, Wan J. Are stone protocol computed tomography scans mandatory for children with suspected urinary calculi? Urology 2011; 78: 662-6.

17. Tisdale BE, Siemens DR, Lysack J, Nolan RL, Wilson JW. Correlation of CT scan versus plain radiography for measuring urinary stone dimensions. Can $\mathbf{J}$ Urol 2007; 14: 3489-92.

18. Wang LJ, Wong YC, Chuang CK, Chu SH, Chen CS, See LC, Chiang YJ. Predictions of outcomes of renal stones after extracorporeal shock wave lithotripsy from stone characteristics determined by unenhanced helical computed tomography: a multivariate analysis. Eur Radiol 2005; 15: 2238-43.

19. Abe T, Akakura K, Kawaguchi M, Ueda T, Ichikawa T, Ito H, Nozumi K, Suzuki K. Outcomes of shockwave lithotripsy for upper urinary-tract stones: a largescale study at a single institution. J Endourol 2005; 19: 768-73.

20. Liu W, Esler SJ, Kenny BJ, Goh RH, Rainbow AJ, Stevenson GW. Low-dose nonenhanced helical CT of renal colic: assessment of ureteric stone detection and measurement of effective dose equivalent. Radiology 2000; 215: 51-4.

21. Lin WC, Uppot RN, Li CS, Hahn PF, Sahani DV. Value of automated coronal reformations from 64-section multidetector row computerized tomography in the diagnosis of urinary stone disease. J Urol 2007; 178: 907-11.

22. Metser U, Ghai S, Ong YY, Lockwood G, Radomski SB. Assessment of urinary tract calculi with 64-MDCT: The axial versus coronal plane. AJR Am J Roentgenol 2009; 192: 1509-13. 
23. Hyams ES, Matlaga BR, Korley FK. Practice patterns in the emergency care of kidney stone patients: an analysis of the National Hospital Ambulatory Medical Care Survey (NHAMCS). Can J Urol 2012; 19: 6351-9.

24. Kalb B, Sharma P, Salman K, Ogan K, Pattaras JG, Martin DR. Acute abdominal pain: is there a potential role for MRI in the setting of the emergency department in a patient with renal calculi? J Magn Reson Imaging 2010; 32: 1012-23.

25. Ripollés T, Martínez-Pérez MJ, Vizuete J, Miralles S, Delgado F, Pastor-Navarro T. Sonographic diagnosis of symptomatic ureteral calculi: usefulness of the twinkling artifact. Abdom Imaging 2013; 38: 863-9.

26. Rafi M, Shetty A, Gunja N. Accuracy of computed tomography of the kidneys, ureters and bladder interpretation by emergency physicians. Emerg Med Australas 2013; 25: 422-6. 